\section{Acknowledgement}

The authors are highly indebted to Prof. $P$. $L$. Bhatnagar for his help and guidance throughout the preparation of this paper.

\section{References}

1) Bhatnagar, P.L., Renuka Rajagopalan, (Miss) and R. K. Bhatnagar (tender print in J. Phys. Soc. of Japan).

2) Oldroyd, J. G., Proc. Roy. Soc. 200 A, 523, 1950.
3) Rivlin, R.S. and J. L. Ericksen, J. Rat. Mech. Anal. 4, 329, 1955.

4) Bhatnagar, $P . L$. and (Miss) G. K. Rajeswari, Indian J. Math. 5, 93, 1963.

5) Frater, K. R., J. Fluid Mech. 19, 175, 1964.

Authors' address :

Miss Dr. Renuka Rajagopalan and Dr. R. K. Bhatnagar, Department of Applied Mathematics, Indian Institute of Science, Bangalore 12 (India)

From the University of Michigan, Ann Arbor, Michigan (USA)

\title{
On the Viscosity of a Fluidized System
}

\author{
By J.D. Murray
}

(Received July 26, 1966)

\section{Introduction}

Fluidized states have many properties which can be described on a continuum basis. This continuum approach has been exceedingly useful in determining fluid mechanical properties of such two phase fluid flows in general and the particular application to bubble motion in fluidized beds has been notably successful and useful [see, for example, Jackson (1), Davidson and Harrison (2) and Murray (3), (4)].

In view of the fluid-like state of fluidized beds considerable work has been devoted to determining an apparent viscosity for such a 'fluid' in the Newtonian sense. A wide range of values has been suggested for such a viscosity. A summary of these is given by Davidson and Harrison (2). More recently Daniels (5) has given the results of a detailed study on the measurement of the drag on spheres immersed in fluidized beds.

The usual methods for finding the viscosity of a normal Newtonian fluid such as the falling sphere method, the rotating cylinders method, etc. are not necessarily reliable when applied to fluidized beds. The main reason for this is that fluidized beds are unstable to small internal disturbances which can give rise to bubbles in the bed. Bubbles in fluidized beds seem to occur when the density of the solid particles is greater than about ten times that of the fluidizing fluid. The stability of fluidized beds was discussed by Jackson (1) and Murray (3) and (6), who suggested governing equations of motion for fluidized beds. Thus, any body introduced into a fluidized bed could create disturbances which could result in viscosity measurements of doubtfull interpretation. The wide divergence of values for the viscosity suggested, from single figure values to tens of poise, are testament to this.

Murray (6) suggested, theoretically, very approximate expressions for a particulate continuum shear and bulk viscosity. He showed that the presence of a bulk viscosity, which may also be thought of as a particle collision effect, was responsible for the rapid damping of surface waves in a fluidized bed.

It seemed that one way of assessing an order of magnitude value to a shear viscosity would be to study some phenomenon which could be observed without artificially disturbing the fluidized bed. This would then provide an independent guide as to the reliability of the accepted techniques as applied to fluidized beds. One such obvious phenomenon is the motion of a bubble: bubbles are endemic in gas fluidized beds. This is done in this paper and it is shown that a value for a shear viscosity (which depends on the voidage) in the vicinity of, but generally less than, ten seems to be indicated. This is in line with the values now generally accepted [see Davidson and Harrison (2) and Daniels (5)] and found by the usual methods when carefully used. The simple method described here thus lends theoretical justification to this value. The method consists simply of estimating the drag on a small bubble and calculating a drag coefficient. The drag, in steady motion, is equal to the buoyancy force and equating them gives a value for the shear viscosity [with the form suggested by Murray (5)].

The form for the viscosity results in an expression for the velocity of rise of a bubble in a fluidized bed which depends on the 
voidage in such a way that the velocity increases when the voidage increases. This is consistent with the experimental results found by Rowe and Partridge (7).

\section{Bubble Motion and the Connection with the Viscosity}

In fluidized beds where bubbles appear the gas momentum resulting from bubble motion is negligible when compared with the particulate motion. Murroy (6) showed that when a bubble moves steadily upwards through a fluidized bed in which it can exist an approximate solution of the equations of motion is that in which the voidage $\varepsilon$ is constant. A consequence of this solution is that the solids motion round the bubble can be approximated by an irrotational flow.

We consider the bubble (three dimensional) to be small and such that the particulate motion relative to the spherical bubble is given by the usual potential $\Phi$, where

$$
\Phi=-U_{B} \cos \theta\left(r+a^{3} / 2 r^{2}\right),
$$

where $U_{B}$ is the velocity of rise of the bubble with radius $a$, and $r, \theta$ the axially symmetric polar co-ordinates measured from the bubble center.

The drag on a bubble (in a liquid) if it is sufficiently small so that it may be considered spherical was given by Levich (8) using the dissipation method [see also Levich (9) and Landau and Lifshitz (10)]. This result has been confirmed by a more rigorous study of the actual viscous problem by Moore (11). We here use the dissipation method with the particulate phase as the fluid.

The rate of change $\dot{E}$ of the kinetic energy of the system due to the bubble motion is thus approximated in this case in the usual way from [1] [see, for example, Landau and Lifshitz (10)] since here the gas momentum is negligible compared with the solids momentum, and is given by

$$
\dot{E}=-12 \pi \mu_{s} a U_{B}^{2},
$$

where $\mu_{s}$ is formally the particulate continuum shear viscosity. The viscous $\operatorname{drag} F_{v}$ is obtained from [2] as

$$
F_{v}=12 \pi \mu_{s} a U_{B}
$$

from which a viscous drag coefficient $C_{D_{v}}$ can be defined as

$\left.\begin{array}{rl}C_{D_{v}} & \left.=12 \pi \mu_{s} a U_{B} / \frac{1}{2} \varrho \pi a^{2} U_{B}^{2}=24 / R e_{s}^{*}\right), \\ R e_{s} & =\varrho U_{B} a / \mu_{s},\end{array}\right\}$

*) Note that the drag coefficient for a small spherical bubble rising up through a fluid is tuice that for a solid particle of the same size in Stokes flow. where $R e_{s}$ is a particulate continuum Reynolds number and where $\varrho$ is the bulk density of the bed which in gas fluidized beds is given by

$$
\varrho \div \varrho_{s}(1-\varepsilon)
$$

where $\varrho_{s}$ is the density of the particles and $\varepsilon$ the voidage.

A bouyancy force $F_{b}$ is given by

$$
F_{b} \doteqdot \frac{4}{3} \pi \alpha^{3} \varrho_{s}(1-\varepsilon) g \text {. }
$$

A buoyancy coefficient $C_{D_{b}}$ for the bubble is thus

$$
\begin{aligned}
C_{D_{b}} & =\frac{4}{3} \pi a^{3} \varrho_{S}(1-\varepsilon) g / \frac{1}{2} \pi a^{2} \varrho_{s}(1-\varepsilon) U_{B}^{2} \\
& =\frac{8}{3} \frac{a g}{U_{B}^{2}} .
\end{aligned}
$$

Murray (4) gave the following expression for $U_{B}$ :

$$
U_{B}^{2}=a g / 3 c,
$$

where $c$ is a constant, introduced in his analysis which can be chosen to enable the solutions obtained to approximate more closely the actual physical situation. In that work, which was essentially an inviscid theory, a value of $c=0.6$ was found theoretically for $c$. From the above, a dependence of $U_{B}$ (and c) on the Reynolds number can be found as follows. Substitution of [8] into [7] gives

$$
C_{D_{b}}=8 \mathrm{c} .
$$

Since in steady motion $C_{D_{v}}$ and $C_{D_{b}}$ are equal, the last equation and [4] imply that

$$
R e_{s}=3 / c
$$

and so

$$
U_{B}^{2}=a g R e_{s}[9 .
$$

An estimate of a value for $\mu_{s}$ can be given from the second of [4], [8] and [10], since from these

$\mu_{s}=\varrho_{s}(1-\varepsilon) U_{B} a c / 3=\frac{1}{3} \varrho_{s}(1-\varepsilon)\left(\operatorname{cg} a^{3} / 3\right)^{1 / 2}$.

Eq. [11] might be expected to hold for small $a$, and gives $\mu_{s}$ as a function of $a, c, \varepsilon$, $\varrho_{s}$. A typical value is given with $\varrho_{s} \fallingdotseq 3 \mathrm{gm}$. c.c., $a=1 \mathrm{~cm} . \quad c=0.6$ [suggested by Murray [4)], $\varepsilon=0.4$, as $\mu_{s} \fallingdotseq 10 \mathrm{gm} / \mathrm{cm} \mathrm{sec}$. Recently Rowe and Partridge (7) showed experimentally that if the volume wake fraction $f_{w}$ of a bubble is zero then $c=0.3$ in which case, from [11], $\mu_{s} \doteqdot 7$ poise. These values can only be order of magnitude values since $a$ in $[11]$ is in a sense arbitrary. The $a$, in fact, must be small enough so that the bubble may be approximately taken to be 
spherical. It may have to be smaller than $1 \mathrm{~cm}$. However, $1 \mathrm{~cm}$. is not an unreasonable value to take and with it the apparent viscosity is in the range of values now fairly generally accepted [see Davidson and Harrison (2)]. It does not support the value of tens of poise as has been suggested.

If the concept of an apparent Newtonian viscosity is pursued (even though there is a dependence on the bubble radius and other quantities) comparison can be made with the results obtained from experiments on the steady rate of fall of a small solid sphere through a bed at incipient fluidization. Partridge (12) reports that a sphere of radius $a=0.75 \mathrm{~cm}$. in a bed of particles of diameter 460 microns with $\varepsilon=0.4$ and $\varrho_{s} \fallingdotseq 3 \mathrm{gm}$./c.c. and sphere density $7.78 \mathrm{gm} . / \mathrm{c.c}$. had a terminal velocity of $U_{t}=50 \mathrm{~cm} . / \mathrm{sec}$. With the value of $\mu_{s} \fallingdotseq 7$ poise from above for $f_{w}=0$, a Reynolds number

$$
R e_{s}=\varrho_{s}(1-\varepsilon) U_{t} \alpha / \mu_{s} \doteqdot 9.6,
$$

is obtained. A drag coefficient $C_{D}$ is given by

$$
\begin{aligned}
C_{D} & =\frac{4}{3} \pi a^{3}\left(\varrho_{\text {sphere }}-\varrho_{s}(1-\varepsilon)\right) g / \frac{1}{2} \pi a^{2} \varrho_{s} \\
& \times(1-\varepsilon) U_{t}^{2} \doteqdot 3.5 .
\end{aligned}
$$

From a typical Newtonian $C_{D}$-Re curve, $C_{D} \fallingdotseq 4.2$ for $R e \fallingdotseq 9.6$. Alternatively, from the last equation for a $C_{D} \fallingdotseq 3.5$, the $R e \fallingdotseq 7.2$. These results are not too inconsistent and are in line with values found experimentally by Daniels (5).

From the second of [4], [8] and [10]

$$
U_{B}=\varrho_{s}(1-\varepsilon) a^{2} g / 9 \mu_{s},
$$

and if $\mu_{s}$ is given as a function of $\varepsilon$ then so is $U_{B}$. Murray (5) suggested a rough and approximate form for $\mu_{s}$ in the situation. where the particles are $2(a+l)$ apart and $l \ll a$ as

$$
\mu_{s} \doteqdot A \mu a / l,
$$

where $\mu$ is the viscosity of the actual fluid and $A$ some function of the geometry. A dependence of $a / l$ on $\varepsilon$ can be obtained as follows.

Consider a cube containing $n^{3}(\gg 1)$ uniformly packed particles of radius $a$ and distance $2(a+l)$ apart. For this cube the volume of the particles plus the interstitial space equals the volume of the cube. Thus

$$
\frac{4}{3} \pi a^{3} n^{3}+\text { interstitial space }=[2 n(l+a)]^{3} .
$$

Dividing both sides by $[2 n(l+a)]^{3}$ we get the following expression for $a / l$ in terms of $\varepsilon$, the voidage fraction and $\varepsilon_{s}$, the close packed or saturation value of $\varepsilon$ (that is when $l=0)$ :

$$
a / l=(1-\varepsilon)^{1 / 3} /\left[\left(1-\varepsilon_{s}\right)^{1 / 3}-(1-\varepsilon)^{1 / 3}\right] .
$$

Substitution of [14] into [13] and then [12] shows that

$$
U_{B} \propto \varrho_{s} a^{2}(1-\varepsilon)^{2 / 3}\left[\left(1-\varepsilon_{s}\right)^{x / 3}-(1-\varepsilon)^{1 / 3}\right], \quad[15]
$$

which shows that $U_{B}$ increases as $\varepsilon$ increases from $\varepsilon_{s}$. There is a value of $\varepsilon$ when $U_{B}$ starts to decrease again, namely for

$$
\varepsilon>1-\left(\frac{2}{3}\right)^{3}\left(1-\varepsilon_{s}\right),
$$

but this region is not in the range found in fluidized beds. The fact that $U_{B}$ increases with increasing $\varepsilon$ has been found experimentally by Rowe and Partridge (7).

\section{Summary}

By considering a fluidized state to be similar to a 'fluid' with a given density, which depends on the voidage, a rough order of magnitude for the apparent shear viscosity of the 'fluid' was found from a simple study of bubble motion in the fluidized state. A value for the viscosity of about 10 poise, or less, was found, which is in line with more recent suggested values.

Using an expression for the continuum shear viscosity and bubble rise velocity given by the author previously a dependence of the bubble velocity on the voidage was indicated which showed that in fluidized states the velocity of rise increased with increasing voidage. This is in keeping with experimental observation.

It should be noted both from the above and previous work in this area that the concept of a fluidized state as a simple Newtonian fluid is limiting. With a Newtonian concept, however, considerable quantitative information has been found. This, not unexpectedly, has been in the area which might be described as the 'inviscid' fluidized state.

I would like to thank Mr. B. A. Partridge of the Chemical Engineering Division, Atomic Energy Research Etablishment, Harwell, England, for kindly supplying details of some of the experimental work quoted above and for the careful criticism and the time he gave to some of my ideas on the viscosity of a fluidized system.

\section{References} (1963).

1) Jackson, R., Trans. Inst. Chem. Engrs. 41, 13

2) Davidson, J. F. and D. Harrison, Fluidised Particles (Cambridge 1963).

3) Murray, J. D., Harvard University, Div. Engrg. Appl. Phys. National Science Foundation Grant GP. 2226 Rep. No. 1. (1963).

4) Murray, J. D., J. Fluid Mech. 22, 57 (1965).

5) Daniels, T. C., Rheologica Acta 4, 192 (1965).

6) Murray, J. D., J. Fluid Mech. 21, 465 (1965).

7) Rowe, $P . N$. and $B$. A. Partridge, Trans. Inst. Chem. Engrs. 43, 157 (1965). 
8) Levich, V., Zh. Eksptl. i Teoret. Fiz. 19, 18 (1949).

9) Levich, $V$. , Physicochemical Hydrodynamics (Pentrice Hall 1962).

10) Landau, L. D., and E. M. Lifschitz, Fluid Mechanics (London 1959).
11) Moore, $D . W .$, J. Fluid Mech. 16, 161 (1963).

12) Partridge, B. A., Private communication (1965).

Author's address:
Dr. J. D. Murray, University of Michigan, Ann Arbor,

Aus dem Institut für Physikalische Chemie der Rheinisch-Westfälischen Technischen Hochschule Aachen

\title{
Die Volumenretardation des Polystyrols nach Druck= und Temperatursprüingen*)
}

\author{
Von Günther Goldbach und Günther Rehage
}

Mit 35 Abbildungen

(Eingegangen am 24. Oktober 1966)

\section{Vorhemerkungen}

Unter Nachwirkung wird die zeitlich verzögerte Einstellung eines Gleichgewichtszustandes auf Grund einer äußeren Beanspruchung des Materials verstanden. Hierbei wollen wir zwei Erscheinungen der Nachwirkung unterscheiden:

a) Die Relaxation: Extensive Größen wie z. B. das Volumen oder die Verformung werden vorgegeben. Die zeitlichen Änderungen der intensiven Größen, z. B. Druck oder Spannung, werden gemessen.

b) Die Retardation: Hier sind die intensiven Größen vorgegeben, und die zeitlichen Änderungen der extensiven Größen werden beobachtet.

In dieser Arbeit werden Nachwirkungserscheinungen des Volumens an glasig erstarrenden Substanzen untersucht. Es handelt sich demnach um Retardationsvorgänge, deren Ursache und experimenteller Nachweis im folgenden näher erläutert werden sollen.

\section{Ursache und experimenteller Nachweis der Volumenretardation}

Eine Flüssigkeit besitzt bei jeder Temperatur und jedem Druck eine bestimmte, statistischen Gesetzmäßigkeiten gehorchende Anordnung der Moleküle [vgl. (1)]. Hat sich die zu einer vorgegebenen Temperatur und zu einem vorgegebenen Druck gehörende ,,innere Ordnung" der Moleküle eingestellt, so befindet sich die Flüssigkeit im sogenannten ,,inneren thermodynamischen Gleichgewicht". Durch eine Änderung der Temperatur oder des Drucks wird die innere Ordnung der Moleküle gestört, und die Flüssigkeit benötigt eine gewisse Zeit, bis das zu der neuen Temperatur bzw. dem neuen Druck gehörende Gleichgewicht wiederhergestellt ist. Beschreibt man die innere Ordnung der Flüssigkeit mit einem einzigen Ordnungsparameter $\zeta$ oder einem Satz von Ordnungsparametern, so kann man jedem einzelnen Ordnungsparameter $\zeta_{i}$ eine Retardationszeit $\tau_{i}$ zuordnen, die für die Geschwindigkeit der Retardation maßgebend ist. Dabei ist die Retardationszeit $\tau_{i}$ als diejenige Zeit definiert, in der die Gleichgewichtsstörung auf den e-ten Teil des Augsangswertes abgeklungen ist. Nun erfordert jede Störung (Temperaturbzw. Druckänderung) eines Gleichgewichts eine gewisse Zeit, die aus experimentellen Gründen nicht unterschritten werden kann. Diese Zeit sei mit „Meßzeit" bezeichnet. Im Falle einer Temperaturänderung z. B. ist die Meßzeit die Zeit, innerhalb der die Flüssigkeit die neue Temperatur annimmt. Solange die größte Retardationszeit $\tau_{i}$ kleiner ist als die Meßzeit, befindet sich die Flüssigkeit während der Dauer des Experiments im inneren Gleichgewicht. Sind eine oder mehrere der Retardationszeiten jedoch größer als die Meßzeit, so erreicht die Flüssigkeit während dieser Zeit nicht mehr ihren Gleichgewichtszustand. Man beobachtet dann z. B. eine Retardation des Volumens; die Ordnungsparameter $\zeta_{i}$ ändern sich dabei in Richtung auf die zum neuen Gleichgewicht gehörende Ordnung. Es sei nun kurz erwähnt, wie sich die vorausgegangenen Betrachtungen während des glasigen Erstarrens einer Flüssigkeit experimentell äußern:

Mißt man bei konstantem Druck $P_{1}$ das Volumen $V$ einer glasig erstarrenden Substanz bei konstanter Abkühlgeschwindigkeit, von hoher Temperatur beginnend, so be-

*) Vorgetragen von $G$. Goldbach auf dem Symposium der Niederländischen Rheologischen Gesellschaft in Valkenburg (Niederlande), am 17. Mai 1966. Kurzfassung in Rheologica Acta 5, 302 (1966) erschienen. 